Civic Life in the Information Age 
This page intentionally left blank 


\title{
Civic Life in the Information Age
}

Politics, Technology, and Generation X

\author{
Stefanie Sanford
}




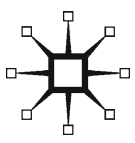

CIVIC LIFE IN THE INFORMATION AGE

Copyright (C) Stefanie Sanford, 2007.

Softcover reprint of the hardcover 1st edition 2007 978-1-4039-7634-5

All rights reserved.

First published in hardcover in 2007 by PALGRAVE MACMILLAN ${ }^{\circledR}$ in the United States - a division of St. Martin's Press LLC, 175 Fifth Avenue, New York, NY 10010.

Where this book is distributed in the UK, Europe and the rest of the world, this is by Palgrave Macmillan, a division of Macmillan Publishers Limited, registered in England, company number 785998, of Houndmills, Basingstoke, Hampshire RG21 6XS.

Palgrave Macmillan is the global academic imprint of the above companies and has companies and representatives throughout the world.

Palgrave ${ }^{\circledR}$ and Macmillan ${ }^{\circledR}$ are registered trademarks in the United States, the United Kingdom, Europe and other countries.

ISBN 978-1-137-29927-7

ISBN 978-0-230-60312-7 (eBook)

DOI 10.1057/9780230603127

The Library of Congress has cataloged the hardcover edition as follows:

Sanford, Stefanie.

Civic life in the information age / by Stefanie Sanford. p. $\mathrm{cm}$.

Includes bibliographical references and index.

1. Generation X-United States-Political activity. 2. CitizenshipUnited States. 3. Internet-Social aspects_-United States. I. Title.

HQ799.7.S225 2007

305.2420973_090511-dc22

A catalogue record for this book is available from the British Library.

Design by Newgen Imaging Systems (P) Ltd., Chennai, India.

First PALGRAVE MACMILLAN paperback edition: November 2012

10987654321 
To Madeline and Elizabeth, my fabulous nieces 
Whatever you can do or dream you can, begin it. Boldness has genius, power and magic in it....

Johann Wolfgang von Goethe 


\section{Contents}

List of Illustrations $\quad$ ix

Foreword xi

Preface xvii

Acknowledgments $\quad$ xxi

1. The Problems of Citizenship in the Early Twenty-First Century 1

2. History's Standards of Good Citizenship 17

3. Assessing Contemporary Citizenship: The Case for Qualitative Methods

4. Cyber-Democrats and Just-In-Time Social Capital

5. Wireheads as New Minimalists: "I gave at the office" 75

6. Tech Elites: Bridging Old and New Social Capital 105

7. Trailing Xers, Rising Millennials, and Two Clichés 127

8. Embracing and Surfing Social Change: Generation X and New Norms of Civic Life and Social Capital 155

9. Closing Thoughts 183

Epilogue: Implications of Generation X Leadership 193

$\begin{array}{ll}\text { Appendices } & 211\end{array}$

$\begin{array}{ll}\text { Bibliography } & 219\end{array}$

$\begin{array}{ll}\text { Index } & 229\end{array}$ 
This page intentionally left blank 


\section{List of Illustrations}

\section{Figures}

4.1 Classical Attributes and Behaviors of Traditional Citizens Versus Cyber-Democrat Views of Quality Citizenship $\quad 55$

4.2 Cyber-Democrat Continuum of Good Citizenship 56

4.3 Traditional Nations of Citizenship 63

4.4 Cyber-Democrat Citizenship Behaviors 67

\section{Tables}

2.1 Galston's Virtues of Citizenship 18

2.2 Categories of Citizenship $\quad 27$

4.1 Galston's Political Virtues 52

6.1 Classic Civic Leaders 115

6.2 Tech Elites: Generation X Civic Leaders 115

8.1 Classic Good Citizenship 166

8.2 High-Tech Generation X Qualities of Good Citizenship by Cohort 168 
This page intentionally left blank 


\section{Foreword}

The generation raised on Cap'n Crunch, Hannah Barbera, and Star Wars has come of age. Dr. Stefanie Sanford's exploration into this generation, so often overshadowed by the Baby Boomers and rising Millennials, provides a thought-provoking guide to predicting future events and America's response.

I read the first edition of this work in 2009, three years after its release. I regret not reading it sooner because it shows how understanding attitudes, behavior, and generational shift can and will predict future actions. During 2007 and 2008, I was a communications director and spokesperson on the Presidential Campaign of Hillary Clinton. This research helped me understand not only why we lost the Democratic Party's nomination but also how generational shift helped drive an articulate and authentic first-term senator, past my seasoned candidate and a longtime senator and war hero, straight into the White House.

As a late Xer, I held the belief that young people didn't vote. In 2004 and 2008 young voters (under 25) increased their voting rates by a total of 12 percent. ${ }^{1}$ This is significant when compared to a 4 percent increase for 25-44-year-olds and a 1 percent increase for 45-64-yearolds. Despite the surge in turnout, they still had the lowest percentage of voter participation compared to other age groups; however, the sheer volume of their participation and the fact that they overwhelmingly chose Barack Obama over John McCain (66-31 percent) ${ }^{2}$ indicate a generational shift in ideology. These young people represent the most logged on segment in American culture and thus substantiate

${ }^{1}$ US Census Bureau: Voting and Registration in the Election of November 2008, Population Characteristics, Issued May 2010; http://www.census.gov/prod/2010pubs /p20-562.pdf

${ }^{2}$ Pew Research Center Publications: Young Voters in the 2008 Election, November 12, 2008; http://pewresearch.org/pubs/1031/young-voters-in-the-2008-election 
Sanford's claim that technology has become a catalyst for changing the nature of work and communication.

Understanding this generational shift in ideology could explain why this year President Obama "evolved" and publicly endorsed gay marriage. Nearly two-thirds (63 percent) of Millennials and 51 percent of Generation X support marriage equality. ${ }^{3}$ Over the past decade, support has increased among every age group. As Sanford points out, the interactivity of online behavior allows users to share thoughts, talents, and opinions in an uncensored manner to their networks and the masses. The interconnected nature of this medium has propelled efforts like the It Gets Better campaign to share content, fuel an issue, and influence people. As Dr. Sanford foretold, winning over hearts and minds or creating celebrity became easier thanks to YouTube, Facebook, and Twitter.

For instance, in 2007, 12-year-old Justin Bieber's performance in a local talent competition was posted on YouTube for friends and family to view. As more videos were uploaded, his online popularity grew until, ultimately, music executive Scooter Braun stumbled upon Bieber's videos and immediately flew him to Atlanta. Over the next four and a half years, Bieber would sell 15 million albums and become the second most popular celebrity on Twitter amassing more than 20 million followers, four times more than the New York Times.

This emergence of new technology empowers individuals to seamlessly communicate in real-time around a thought or idea and has provided the most dramatic shift in power in my lifetime. Just as Howard Dean raised unprecedented sums of cash online for his 2004 presidential campaign and Barack Obama used Facebook to let "friends" share and validate his message with their "friends," Sanford's updated use of 1973s "strength of weak ties" research has never been more on display than the use of social networking sites in 2011 as a platform to collaborate for the ousting of Libyan leader Muammar Gaddafi and Egyptian president Hosni Mubarak. Social media became a weapon used by the revolutionaries, and their disruptive behavior popularized the use of technology as a catalyst for change.

At home, Generation X's ascension to power and economic uncertainty have left an indelible mark on the political landscape. In 2008, Generation X elected its first president and the 2010 election saw the insurgence of a new group of leaders, the Tea Party,

\footnotetext{
3 The Pew Forum on Religion and Public Life; http://features.pewforum.org/same -sex-marriage-attitudes/slide2.php
} 
made up of self-proclaimed fiscally conservative Republicans who were, overwhelmingly, members of Generation X. The Tea Party rapidly gained a reputation as "obstructionists," refusing to compromise on issues around the debt ceiling. As Dr. Sanford points out, Generation X lives in the reality of the times. And the reality is, our federal government is borrowing and spending at alarming rates. Prior to the election of the Tea Party, two factions were forced to compromise, one side that wanted tax cuts and one that wanted to protect Social Security and Medicare. Since the balanced budgets of the late $1990 \mathrm{~s}$, the compromise has been to raise the debt ceiling.

The lay of the land has changed now that a powerful voting bloc has been established that advocates for debt reduction above all else. These new participants in the process have changed the debate in Washington and in state legislatures across the country. As this work explains, the term "obstructionists" is less fitting and more likely a moniker cast upon increasingly influential Xers by sour members of older generations who are losing power.

Boomers and Millennials dwarf Generation X in size, but the impact of this generation, previously depicted as slackers, is being felt in every sector. In government, disruptive figures like U.S. representative Paul Ryan and Wisconsin governor Scott Walker have shaken up institutions. Ryan, a charismatic young GOP congressional leader, authored a budget that took drastic measures to reign in the federal deficit by altering the Greatest Generation's Medicare, and Wisconsin governor Scott Walker faced a recall spearheaded by labor unions for targeting public employee collective bargaining rights under the guise of saving Wisconsin's budget. These positions, disruptive as they are and depending upon which side of the spectrum you stand, could have been considered profiles in courage by prior generations. Sanford is the first scholar to look at these behavioral patterns through a generational lens instead of a partisan one.

Dr. Sanford offers a rare look into the maturation of these latchkey kids, and her findings may be adapted to consumer behavior, media consumption, and business leadership styles. The traits she identifies can be applied to other sectors like business, media, and entertainment.

For example, Generation X's disruptive behavior is influencing television programming through the likes of Andy Cohen and Ryan Seacrest. These television executives have created celebrities through reality programming and launched the careers of Nene Leakes, Kim Kardashian, and many others. 
In addition, political satirists Jon Stewart of the Daily Show and Stephen Colbert of the Colbert Report have arguably done more to influence the generational shift in ideology than anyone else on television. Their nightly fake news programs garner strong ratings and their audiences are primarily ( 80 percent) under 50 years old. They are not alone; Saturday Night Live comic Tina Fey's portrayal of Republican vice presidential candidate Sarah Palin made her one of the most influential players in the 2008 presidential election, and she was viewed and "shared" online millions of times.

The Internet has exacerbated the 24-hours news cycle from the headline news of CNN and MSNBC to round-the-clock digital coverage of politics, sporting events, and celebrity gossip. Blogger Perez Hilton altered the business of gossip when his self-titled blog attracted millions of users. His coverage upended existing business models and drove dramatic change to the industry. Similarly, Politico, an American political journalism organization heavily influenced by Gen X cofounders John Harris and Jim VandeHei, transformed business models by prioritizing online traffic over print advertising. Today the site hosts some of the most influential columnists and reporters in the Beltway and is a top source for political information.

In Hollywood, Gen X celebrities are proving Sanford correct in being "creators instead of joiners." One shining example is actor Brad Pitt who, following the devastation of Hurricane Katrina, created the Make It Right Foundation to organize the construction of 150 sustainable homes in New Orleans' Ninth Ward. Using his social capital and financial capital, Pitt organized a team of building professionals and other philanthropists to move the project forward. Pitt and others have served as inspiration for my firm, Propper Daley, a social impact agency. Operating at the intersection of entertainment and public policy, we partner with likeminded individuals, organizations, corporations, and causes to create transformational social change.

In response to the fact that 1 million Veterans will be returning over the next three years and those who have returned face higher unemployment than their civilian counterparts, in May of 2012 we launched Got Your 6, Hollywood's campaign to help returning Veterans reintegrate into civilian life. Using a collective impact model we partnered with every major movie studio, television network, and talent agency as well as two dozen national nonprofit organizations to assist military families with jobs, housing, education, and more. Using the assets of our partners we have promoted the campaign through television and movie script integration, digital channels, and visual merchandising. 
This campaign is a living example of Sanford's "just in time" social capital. Our goal, much like her "Cyber-Democrats," is to respond effectively and efficiently to a community need and that is why each of the six pillars of reintegration established in the campaign has a quantifiable goal to measure success.

This book is an essential read for historians, pundits, and anyone interested in understanding the thought and behavioral patterns of latchkey-kids-turned generational leaders. Dr. Sanford's work becomes more and more important as the number of Generation $\mathrm{X}$ leaders occupying corner offices, Senate offices, and the Oval Office continues to grow.

Mark Daley

Partner, Propper Daley Los Angeles, CA 
This page intentionally left blank 


\section{Preface}

I wrote the first version of Civic Life in the Information Age in 2002 and defended it around the dissertation table at the University of Texas in the spring of 2003. I finished the hardcover version in early 2006 amid the Katrina calamity, but well before the much larger calamities to come just a couple of years later.

It is now 2012 and the question for this paperback edition is: What has changed since 2006?

My first thought was: What hasn't changed? There have been huge changes in politics worldwide-driven by the upsurge in social media and the downturn in the global economy. And in the 10 years since this research began, the "crank has turned" with the younger generations in question, "moving up" into positions of personal and societal leadership. This moving up has been profoundly personal to me in the intervening years. My younger sister, the mother of my fabulous nieces to whom this book was-and is still-dedicated, died suddenly on a typical Tuesday afternoon at an amusement park in the summer of 2008. Within 18 months of her death, my mother was diagnosed with cancer, my stepfather died after a long illness, and my grandmother died suddenly, found on the floor of her foyer, cell phone in hand, with a number for help scrolled to the screen too late to hit "send." While I lost three close family members and shifted suddenly from granddaughter to makeshift matriarch, huge numbers of people across America lost their jobs, their homes, much of their wealth, and a good deal of their confidence in the ensuing months. Where I had written this first edition as a young graduate student looking at a world run by others, I revisit this paperback a generation older in my family, two levels up in my workplace, and amid churning changes in the world, large and small.

The nation's first African American and first Generation X president was elected largely on the hopeful, "postideological" enthusiasm 
he had just begun to animate as I was writing in 2005-2006. The huge mobilization of young people who filled stadiums to hear then candidate Obama's message of hope and change gave way to a backlash in 2010, electing a large class of new Republican House members, most of whom were born after 1960. Bookshelves (and Amazon recommendation lists) feature such titles as It's Even Worse than It Looks and theaters such dystopian narratives as The Hunger Games.

I thought the turn of the millennium was filled with civic and social ennui. Little did I know what was in store for the end of that decade. These changes have spurred two social movements: the Tea Party on the right and Occupy on the left. I touch on some of the generational qualities they reflect, but they deserve much more serious inquiry than given in this brief update. Thus far, their ideological soulmates see goodness in those who reflect their views and menace in those with whom they disagree. My preliminary look says there is much more at play in both groups-and in their interplay-than is surfaced by that predictable partisan analysis.

In 2006, Facebook had just emerged from its Ivy League birthplace and no one had heard of "Twitter." Facebook's IPO in May 2012 was among the largest such offering in American history, resulting in the first famous self-made Millennial billionaire. In 2006, Millennials were seen as the direct decedents to the Greatest Generation that served in World War II. They were optimistic joiners providing a welcome rebellion against Generation $\mathrm{X}$ angst and cynicism. Today, Millennials are more often seen in Occupy tents lamenting broken promises of Baby on Board helicopter parents and the information economy as they struggle with student debt and diminished job prospects in the slow growth years that have followed 2008's "Great Recession."

Across the globe, social media, especially Facebook and Twitter, have delivered on their promises to connect more and more people at greater and greater distance. In some ways, they have put my notion of "just-in-time social capital" on steroids. My 2003 examples of e-mail trees to clean up parks or even the 2006 examples of text message fundraising for Katrina and Haiti seem quaint in the wake of the Arab Spring and the 2008 Obama Campaign. Back in 2006, Rupert Murdoch predicted such social media would connect revolutionaries and bring down tyrannical regimes. He was right. Little did he know his own empire would be regularly attacked by Occupy, animated by those very tools. There are more people on Facebook today than there were those who had access to the Internet in 2005. Now, over 
80 percent of people in the world have a mobile phone. This shift from PC-oriented access to smart phone has dramatically reduced the "digital divide" and accelerated the pace of interaction among greater numbers of people at greater distance across the world. This edition features data updates in the first chapter to capture these huge changes in online access.

Here in the United States, Baby Boomer retirements loom large in terms of talent-loss but more so in terms of economics as the sheer size and scale of their generation threatens to bankrupt the nation's entitlement and health care apparatus absent brutal political decisions or serious generational concessions. Generation $\mathrm{X}$ is moving into positions of leadership, and generational differences are coming to the fore, although are typically covered in the media as ideological or partisan fights. In some cases, they are such fights, but in others, I argue, there are other important differences playing out. The decline of traditional institutions and their popular credibility continues, and the pace of this much faster, broader, just-in-time social capital continues to increase. The largest question for me at the center of these seismic shifts among generations, technological advance, and social capital is this: can just-in-time social capital address the social problems we face today? Can such ephemeral interactions among so many, in such short duration and increasingly among those who share a common, narrow ideology be durable enough to replace old civic institutions that provided time, place, and opportunity to connect to address such big and complicated issues? More simply, now what?

To better understand these phenomena I called on a social media expert, fellow observer of politics and occasional policy sparring partner, Mark Daley, principal of the firm Propper Daley. Our conversations about the actuality and potential of social media and the blurring of existing sectors and ideologies to tackle social issues were enormously helpful in drafting the update and concluding chapter of this edition. And the fact that our policy differences dissipated the longer we collaborated showed us that different party affiliations don't necessarily mean wide policy or social ones, whether on support for returning veterans, gay marriage, education, or entitlement reform. I thank him for his insight and partnership. And to update the considerable changes in Internet numbers and a host of other "corrections" made necessary by the passage of time, I thank my able research assistant Cassandra Lodore, a Millennial and new member of my extended family, a blessing brought by marriage five years ago to David Moore, himself a writer and editor (and fighter pilot). 
xx Preface

I have left the previous acknowledgment text and the 2006 closing chapter intact, giving this edition a time-capsule quality. Perhaps any writing on generations must do so, since such inquiry is always aboutand fundamentally altered-by the passage of time.

Stefanie Sanford Moore Rehoboth Beach, DE

May 2012 


\section{Acknowledgments}

I am a part of all that I have met

Tho much is taken, much abides

That which we are, we are-

One equal temper of heroic hearts

strong in will

To strive, to seek, to find, and not to yield.

I have always loved the verse above and think it is especially apropos to open this tome and close this chapter of my life by thanking the people who helped make it possible. They are many. First and foremost, thank you to my adviser, Roderick P. Hart, a great intellect and teacher who fought cynicism on the gridiron of cool and won over and over again. Thank you for all of your help on this project, but most importantly for setting the conditions that make dedications like this possible. Annette would be proud. You do her memory justice every day and it has been a privilege to be a part of that.

To my immediate family - thanks to my mom and dad, their spouses and my siblings (David, that means you, too). Our familial stew has played a huge role in bringing me to this place. I come from a long line of unapologetically strong women. Their spirit runs through my veins and with each adventure I can hear the echo of their legacies in my mind: Mom, Nan, Meem, Aunt Bet, and Aunt "Louise" and of course the three great grandmothers I had the good fortune to know. I spent formative moments with each of these women and for as long as I can remember, I have been imitating them, stalking them, questioning them. They have taught me how to be the grown-up I want to be, how to chase dreams when everyone believes said dreams are nuts, and that, like all good southern women, one should always try to look great regardless of the weather. And in a more concrete and less romantic way, they have 
helped me finance these dreams through their direct investment, their pledges of support, their opportune checks, palmed $\$ 100$ bills at holiday times and their last-minute loan cosignatures. Simply, I would not be here and this book would not exist without each of them.

To the teachers-I have been blessed with thoughtful, compassionate and patient teachers throughout my extended education. Mrs. Leaventhal in fourth grade at Lamplighter was the first to treat me differently because I loved to write. We recently reconnected in Washington-she hasn't changed since those days-and in some ways, neither have I. She admonished, "Please, call me Sheila." In my experience one can never call your greatest elementary school teacher by her first name, even as the fortieth birthday draws near. Dr. Hermann and Dr. Suzuki were violin teachers who gave me an early appreciation of excellence, commitment, and the power of practice and passion over mere memorization. Mr. Schultz taught AP history at Westlake High School and imbued in me forever a sense that history is a living, breathing thing and politics and civic life are its contemporary practices. Long before President Reagan toasted President Kennedy's memory at the rededication of his library, Mr. Schultz taught me that "[h]istory isn't about people, history is people . . . and it is as heroic as you want it to be, as heroic as you are." Dr. Warner even made me write about trigonometry and showed me that even that could be compelling. At TCU, I must thank Drs. Harris, Hall, and Babbili. Dr. Harris taught freshman comp and was the first writing teacher to ever make the apparently conflicting demands-write to the assignment and think hard. After years of glib improvisation in and around assignments, she forced me to risk, to put my real thoughts and philosophies on paper and defend them as an intellectual-not a satirist-would. Dr. Hall first said that she knew I would one day get a $\mathrm{PhD}-\mathrm{I}$ couldn't fathom such a thing, but here it is-she believed it before I did. I can still see her determination for me as we had that conversation. And Dr. B-a good friend and mentor-always ready to take on the tough political challenges on campus and had a way of making writing, journalism, and politics all seem like noble pursuits. It's not so much that I pursued these tasks because he said I should as much as he showed all of us a professional that we could see ourselves proudly becoming. My heartfelt thanks to all of them. Their hair has grayed over the nearly 20 years since I sat in their undergraduate classes, but their wisdom stays with me to this day. Dr. Porter at The Kennedy School engaged me in the study of presidential transitions. That research became the fodder for my White House Fellow application (as his own story became my inspiration). 
He treated me as a scholar and supported this study even as it took me away from the rough and tumble world of public policy for a time. Most importantly, Dr. Porter taught me that in the game (said Teddy Roosevelt) ideas matter (no matter what the cynics say) more than ideology and that in order for good policy to be made, "honest brokers" must exist. I hope this effort has helped me become a better honest broker.

To my gal pals and critics—my best friends Colleen and Loree-for their always pushing me to think harder; for their fearless criticism of my ideas, my wine selection, and my tendency to respond to a social "How's the book going?" with an avalanche of specifics that could send even the most hearty social capitalist fleeing for the bar. Every successful person needs thoughtful, caring critics. I have been blessed with the best-they read and digested the ideas, challenged the principles, and endured the obsession that comes with successfully completing one of these tomes. Couldn't have done it without them.

To my doctorate-holding friends, helpers and cheerleaders, Drs. Sharon Jarvis, Bob Orr, Peter Fiske, and Stephanie Ferguson-many thanks for the late-night advice, strategic insights about the defense, the scope of the project, and the priority I must give to such enterprises if I ever hoped to finish. They were a source of inspiration and countless computer monitor post-it notes reminding me that some day this would be done, I would be glad and it would be a contribution to a national discussion I find vitally important. Obviously, this work could not exist without the my candid and thoughtful respondents and the insights of my mentor and friend, Mike Maples, whose generous spirit and long history in this field helped me sort through the idiosyncrasies of the tech world.

Special thanks must go to my most detail-oriented friend and colleague Ali Khedery. We traveled the postdefense last mile together, checking and rechecking formats, paginations, table numbers, and a host of minutia demanded by MAI 101. He has been in the Green Zone trying to help build a democracy in Baghdad since his days as my right hand in the Governor's Office and the Foundation. I think that if his likely career as a leading diplomat falls through, there could be a job as "margin police" in his future. You're the best-come home soon and safely. Like Ali, my colleagues at the Bill \& Melinda Gates Foundation have been patiently supportive of this obsession since I walked through the door especially Tom Vander Ark and have allowed me to infuse our work with some of these ideas (but by no means all), providing a daily testing ground. It would not have been completed without their goodwill. 
And finally, thanks to my tireless dissertation committee: Larry Leibrock, Daron Shaw, Chuck Whitney and Thurgood Marshall, Jr. I knew you all in some fashion before we gathered on either side of a potentially adversarial table and respected your intellects, humor, style, and professionalism. Geeky as it sounds, I wish we could have met over this topic many more times. Your disciplinary expertise and passion about these topics made each meeting exhilarating and memorable. It was your encouragement during the defense that led to this publication and the introduction of these ideas into a broader arena. Daunting as that proposition is, I will always be eternally grateful for your confidence.

Onward!

PS: There was no logical place to include them in the above acknowledgments, but this project owes a debt to a profound beginning and profound ending that took place over the course of this work. The profound ending was the passing of my grandfather, Dadoo, my feminist role model. He spent his life surrounded by ornery women and seemed to revel in helping us all find our place in the world and laughing along the way. Writing his eulogy helped me get my head around writing this dedication, which is really about being thankful for a lifetime full of smart, funny people. Dadoo helped me fully appreciate just how blessed I've been in that regard. The beginning was the birth of my fabulous nieces, Madeline Jeanne and Elizabeth Jayne Gillan to whom this book is dedicated. These little miracles of genetics carry the names of their ornery women ancestors, Dadoo's humor and wiry hair, and just perhaps the bold and entrepreneurial spirit of my other grandfather, GWF. At six years old, the twins were not even a glimmer when this inquiry began, but as it is complete, it occurs to me that this study is ultimately about them. We have seen a steady decline in the participation of young people in our democracy-and in some ways a systematic devaluing of their role in our continuation and our renewal. I believe to the very core of who I am that this must change and that some of the insights of this study could be catalysts to that sort of change. Magic Mad and the Little Clown give this study an urgency that scholarship or policy alone could never do. So my last dedication must be to them-that we do right by their dreams and bequeath them a democracy worth their tending 